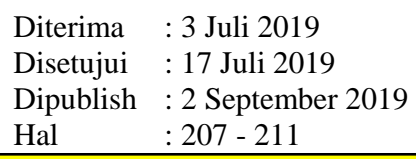

\section{PERLINDUNGAN HUKUM BAGI NASABAH PENGGUNA INTERNET BANKING}

\author{
ALINE FEBRIANY LOILEWEN ${ }^{1)}$, TITIN TITAWATI ${ }^{2)}$ \\ Fakultas Hukum UNMAS Denpasar PSDKU Mataram \\ e-mail: ${ }^{1)}$ alinefebryani@gmail.com, ${ }^{2)}$ titintitawati@gmail.com
}

\title{
ABSTRAK
}

Penelitian ini bertujuan untuk mengkaji dan menganalisis bagaimana perlindungan hukum dan pengawasan dunia perbankan terhadap para nasabah pengguna fasilitas internet banking.

Penelitian ini menggunakan bentuk penelitian hukum normative, yaitu penelitian yang didasarkan pada peraturan-peraturan dan perundang-undangan tertulis dan berbagai literature yang berhubungan dengan permasalahan yang akan dibahas dalam penelitian ini.

Beberapa bentuk perlindungan hukum nasabah pengguna fasilitas internet banking adalah dengan adanya Peraturan Otoritas Jasa Keuangan No.38/POJK.03/2016 tentang Penerapan Manajemen Risiko dalam Penggunaan Teknologi Informasi oleh Bank Umum (POJK Manajemen Resiko TI). Adanya Pasal 1 angka 12 Undang-Undang No 11 Tahun 2008 tentang Informasi dan Transaksi Elektronik (UU ITE), tanda tangan elektronik adalah tanda tangan yang terdiri atas informasi elektronik yang dilekatkan, terasosiasi atau terkait dengan informasi elektronik lainnya yang digunakan sebagai alat verifikasi dan autentikasi. Hal lain yang bisa dilakukan oleh nasabah pengguna fasilitas internet banking adalah melakukan pengaduan nasabah, Pengaduan nasabah adalah bentuk perwujudan dari perlindungan hak yang dimiliki oleh nasabah yaitu hak untuk di dengar. Hak tersebut diatur di dalam Pasal 4 huruf d Undang-Undang 8 Tahun 1999 tentang Perlindungan Konsumen UU PK). Sedangkan pada sektor jasa keuangan, terdapat Pasal 32 Peraturan Otoritas Jasa Keuangan Nomor 1/POJK.07/2013 tentang Perlindungan Konsumen Sektor Jasa Keuangan (POJK PK) yang mengatur bahwa pelaku usaha sektor jasa keuangan wajib memiliki dan melaksanakan pelayanan dan penyelesaian pengaduan nasabah.

Kebijakan pengawasan yang dilakukan oleh Bank Indonesia terhadap perbankan bertujuan untuk melindungi kepentingan masyarakat dan serta menjaga kelangsungan usaha bank sebagai kepercayaan dan sebagai lembaga intermediasi, pengawasan tersebut dilaksanakan baik secara langsung ataupun tidak langsung.

Kata kunci : Perlindungan hukum fasilitas internet banking

\section{ABSTRACT}

This study aims to examine and analyze how the legal protection and supervision of the banking world for customers using internet banking facilities.

This study uses a form of normative legal research, namely research that is based on written rules and legislation and various literature related to the problems that will be discussed in this study.

Some forms of legal protection for customers using internet banking facilities are the existence of the Financial Services Authority Regulation No.38 / POJK.03 / 2016 concerning Application of Risk Management in the Use of Information Technology by Commercial Banks (POJK IT Risk Management). The existence of Article 1 number 12 of Law No. 11 of 2008 concerning Information and Electronic Transactions (UU ITE), electronic signatures are signatures consisting of electronic information that is attached, associated or related to other electronic information used as a verification and authentication tool. Another thing that can be done by customers who use internet banking facilities is to conduct customer complaints. Customer complaints are a manifestation of the protection of rights owned by customers, namely the right to be heard. This right is regulated in Article 4 letter $d$ of Law 8 of 1999 concerning Consumer Protection of the PK Law). Whereas in the financial services sector, there is Article 32 of the Financial Services Authority Regulation No. 1 / POJK.07 / 2013 concerning Consumer Protection in the Financial Services Sector (POJK PK) which stipulates that financial service sector business operators must have and carry out customer service and settlement complaints.

The supervision policy carried out by Bank Indonesia towards banks aims to protect the interests of the community and to maintain the continuity of the bank's business as a trust and as an intermediary institution, the supervision is carried out either directly or indirectly. 


\section{PENDAHULUAN}

\section{Latar Belakang}

Beranjak dari pemikiran bahwa dewasa ini, fasilitas internet banking sangat dibutuhkan oleh sebagian besar masyarakat dunia. Hal ini dikarenakan dengan menggunakan fasilitas internet banking segala urusan kehidupan kita menjadi lebih mudah, mulai dari pembayaran sampai dengan pembelian barang dan jasa jadi lebih mudah untuk dilakukan dengan hanya menggunakan fasilitas internet banking. Dengan menggunakan internet banking kita jadi lebih bisa menghemat waktu dan tenaga dengan tidak perlu mengantre di kantorkantor bank atau ATM, karena saat ini banyak transakasi perbankan bisa dilakukan dimanapun dan kapanpun dengan lebih mudah dan praktis melalui jaringan elektronik, misalnya menggunakan telpon,handphone dan internet. Contoh nyata yang sering bisa dilakukan oleh para pengguna fasilitas internet banking adalah pembelian pulsa isi ulang, pengecekan saldo rekening, transfer dana antar rekening dan pembayaran tagihan (listrik,air,telpon,dll).

Banyak kemudahan, kelebihan dan juga nilai tambah dari penggunaan fasilitas internet banking, mulai dari fleksibilitas, efisiensi, hingga kesederhanaan, tetapi banyak juga kekurangan yang harus dihadapi oleh para nasabah pengguna fasilitas internet banking, resiko besar yang mungkin dihadapi oleh para nasabah pengguna fasilitas internet banking apabila tidak dilakukan antisipasi sedini mungkin. Internet banking yang mempunyaibasis teknologi informasi dalam penyelenggaraannya rawan dengan adanya penyalahgunaanoleh orang-orang yang tidak bertanggung jawab baik dari dalam maupun dari luar lembagaperbankan. Hal tersebut dibuktikan dengan laporan Otoritas Jasa Keuangan (OJK) mengenaibesarnya jumlah fraud yang terjadi pada transaksi mobile banking dan internet banking hinggaJuni 2015 sebanyak 3.373 kasus dengan nilai kerugian yang mencapai Rp. 104,58 miliar (http://www.antaranews.com 20 Mei 2019), sehingga penting adanya perlindungan yang diberikankepada nasabah pengguna layanan atau fasilitas internet banking.

Melihat semua fenomena yang terjadi belakangan ini yang berhubungan dengan perlindungan nasabah pengguna fasilitas internet banking, sedangkan pada dasarnya perlindungan hukum kepada nasabah merupakan hal yang sangat essential melihat adanya fungsi bank sebagai agent of trust. Bank sebagai agen of trust dengan dasar utama kegiatan perbankan adalah trust atau kepercayaan, baik dalam menyalurkan dana maupun dalam menghimpun dana. Besarnya kepercayaan nasabah terhadap sistem elektronik berkaitan dengan besarnya kepercayaan mereka terhadap online banking.Dengan demikian hal ini membangun sebuah pertanyaan bagaimanakah perlindungan hukum nasabah pengguna fasilitas internet banking dan bagaimanakah pengawasan dunia perbankan terhadap para nasabah pengguna fasilitas internet banking.

\section{Perumusan Masalah}

Dari uraian di atas dapat dirumuskan permasalahab sebagai berikut:

1. Bagaimanakah perlindungan hukum nasabah pengguna fasilitas internet banking?

2. Bagaimanakah pengawasan dunia perbankan terhadap para nasabah pengguna fasilitas internet banking?

\section{Tujuan Penelitian}

Penelitian ini bertujuan untuk mengkaji dan menganalisis bagaimana perlindungan hukum dan pengawasan dunia perbankan terhadap para nasabah pengguna fasilitas internet banking.

\section{METODE PENELITIAN}

Penelitian ini menggunakan bentuk penelitian hukum normative, yaitu penelitian yang didasarkan pada peraturan perundang-undangan tertulis dan berbagai literature yang berhubungan dengan permasalahan yang akan dibahas dalam penelitian ini.

Sumber-sumber penelitian hukum dapat dibedakan menjadi sumber-sumber penelitian yang berupa bahan-bahan hukum primer yang terdiri dari perundang-undangan dan putusan-putusan hakim, sedangkan bahan sekunder berupa semua publikasi tentang hukum yang bukan merupakan dokumentasi resmi, publikasi tentang hukum meliputi buku-buku teks, kamus-kamus hukum, jurnal-jurnal hukum dan komentar-komentar tentang hukum. 
Bahan-bahan hukum yang diperoleh lewat penelitian kepustakaan yang meliputi bahan hukum primer, bahan hukum sekunder dan bahan hukum tersier. Bahan hukum hyang diperlukan, diinventarisasi kemudian bahan hukum yang berkenaan dengan pokok masalah atau tema sentral diidentifikasi untuk digunakan sebagai bahan analisis yang dilakukan pada awal penelitian dan juga selama penelitian ini berlangsung sehingga didapatkan suatu kesimpulan dan juga saran yang bermanfaat untuk hasil penelitian. Di dalam penelitian hukum normative, analisa terhadap asas-asas hukum dilakukan terhadap kaidah-kaidah hukum yang merupakan patokan-patokan berprilaku atau bersikap tidak pantas.

\section{PEMBAHASAN}

\section{Perlindungan Hukum Nasabah Pengguna Fasilitas Internet Banking}

Perlindungan hukum adalah upaya melindungi kepentingan seseorang dengan cara mengalokasikan suatu kekuasaan kepadanya untuk bertindak dalam rangka kepentingannya itu Satjipto Raharjo (2003:121). Perlindungan hukum selalu dikaitkan dengan konsep rechtstaat atau konsep rule of law karena konsep tersebut lahir dari keinginan manusia di dalam memberikan pengakuan dan perlindungan terhadap hak asasi manusia.

Pengertian Nasabah menurut Peraturan Bank Indonesia No.7/7/PBI/2005 jo No. 10/10/PBI/2008 tentang penyelesaian pengaduan nasabah dalam pasal 1 angka 2 yang dimaksud dengan nasabah adalah pihak yang menggunakan jasa bank, termasuk pihak yang tidak memiliki rekening namun memanfaatkan jasa bank untuk melakukan transaksi keuangan.

Internet banking adalah istilah yang sering juga disebut dengan electronic banking atau E-Bankingyang diartikan sebagai suatu aktivitas transaksi yang berhubungan dengan perbankan, dimana aktivitas tersebut bisa dilakukan di kantor, rumah atau tempat-tempat lainnya dengan menggunakan jaringan internet.

Beberapa bentuk perlindungan hukum bagi nasabah pengguna fasilitas internet banking adalah sebagai berikut: OJK membuat Peraturan Otoritas Jasa Keuangan No.38/POJK.03/2016 tentang Penerapan Manajemen Risiko dalam Penggunaan Teknologi Informasi oleh Bank Umum (POJK Manajemen Resiko TI). Adanya pengaturan baik berupa undang-undang maupun peraturan Otoritas Jasa Keuangan diharapkan dapat mengakomodir semua kebutuhan perlindungan hukum bagi nasabah yang akan melakukan transaksi internet banking.Bank dalam menjalankan pengamanan terhadap teknologi informasinya menerapkan 3 prinsip yaitu prinsip kerahasiaan (confidentiality), integritas (integrity), dan ketersediaan (availability). 3 prinsip yang diterapkan oleh Bank ini sesuai dengan Pasal 16 huruf a POJK Manajemen Risiko TI.

Selain menggunakan teknologi-teknologi tertentu untuk melindungi kerahasiaan dalam penggunaan internet banking, Bank juga menggunakan metode multi factor autentication yaitu what you know (username dan password) dan what you have (token) untuk memeriksa apakah pengguna internet banking merupakan pengguna yang sah. Fungsi username, password dan Token PIN tidak hanya merupakan bentuk autentikasi pengguna yang sah.Namun username, password dan Token PIN juga dapat dikategorikan sebagai sebuah tanda tangan elektronik. Berdasarkan Pasal 1 angka 12 Undang-Undang No 11 Tahun 2008 tentang Informasi dan Transaksi Elektronik (UU ITE), tanda tangan elektronik adalah tanda tangan yang terdiri atas informasi elektronik yang dilekatkan, terasosiasi atau terkait dengan informasi elektronik lainnya yang digunakan sebagai alat verifikasi dan autentikasi. Tanda tangan elektronik pada prinsipnya berkenaan dengan jaminan untuk message integrity yang menjamin bahwa si pengirim pesan (sender) adalah benar-benar orang yang berhak dan bertanggungjawab untuk itu.Hal ini berbeda dari tandatangan biasa yang berfungsi sebagai pengakuan dan penerimaan atas isi pesan atau dokumen.

Prinsip terakhir dalam pemenuhan keamanan teknologi informasi di Bank adalah prinsip ketersediaan. Prinsip ketersediaan adalah prinsip yangmenekankan ketersediaan hubungan informasi ketika dibutuhkan oleh nasabah, dalam Pasal 17 UU ITE, mengatur salah satu bentuk penerapan prinsipketersediaan yaitu penanggulangan gangguan atau bencana (Disaster RecoveryPlan). Bank untuk menjaga prinsip ketersediaan juga membuat disasterrecovery plan yang digunakan untuk pencegahan terhadap beberapa gangguan.Selain membuatdisaster recovery plan untuk memenuhi prinsip ketersediaanBank juga menyediakan sarana backup hardware.Untuk memastikan sarana server backup internet bankingtersebut dapat berjalan dengan baik pada saat dibutuhkan.Maka Bank bisa melakukan uji coba secara berkala dalam jangka waktu minimal 6 bulan sekali dengan memperhatikan tingkat kritikal yang terjadi. Dengan ini maka Bank telah memenuhi setiap prinsip kerahasiaan (confidentiality), integritas (integrity), dan ketersediaan (availability) dalam melakukan pengamanan informasi dalaminternet banking sesuai dengan Pasal 16 huruf a POJK Manajemen Resiko TI. 
Hal lain yang bisa dilakukan oleh nasabah pengguna fasilitas internet banking adalah dengan melakukan pengaduan nasabah, Pengaduan nasabah adalah bentuk perwujudan dari perlindungan hak yangdimiliki oleh nasabah yaitu hak untuk di dengar. Hak tersebut diatur di dalam Pasal4 huruf d UndangUndang 8 Tahun 1999 tentang Perlindungan Konsumen UU PK).Sedangkan pada sektor jasa keuangan, terdapat Pasal 32 Peraturan Otoritas JasaKeuangan Nomor 1/POJK.07/2013 tentang Perlindungan Konsumen Sektor JasaKeuangan (POJK PK) yang mengatur bahwa pelaku usaha sektor jasa keuanganwajib memiliki dan melaksanakan pelayanan dan penyelesaian pengaduan nasabah.Bank sebagai pelaku usaha sektor jasa keuangan juga telahmenyediakan sarana untuk nasabah melakukan pengaduan yang dapat dilakukansecara tertulis maupun secara lisan. Sarana tersebut terbagi antara lain: 1) CallCenter, 2) Media Sosial (Facebook, Twitter), 3) Layanan Konsumen OJK, 4)Service Assistant, 5) Surat kepada Bank, 6) E-mail kepada Bank. Pengaduanyang dilakukan nasabah dengan sarana tersebut akan dicatat dan akan langsung diselesaikan oleh Bank. Apabila dilakukan pada kantor cabang, penyelesaianpengaduan nasabah akan dilakukan oleh service assistant yang terdapat di masing-masingkantor cabang. Sedangkan di kantor pusat akan langsung diselesaikan olehDivisi Pembinaan Cabang. Apabila nasabah telah puas dengan jawaban pihak bank, maka pengaduan nasabah akan dianggap selesai. Namun apabila nasabah belum puas, maka bank akan menyelesaikan pengaduan nasabah dengan batas waktu maksimal20 hari kerja sesuai dengan Pasal 35 POJK Perlindungan Konsumen. Jika denganadanya penambahan waktu hingga 20 hari kerja Bank belum bisamenyelesaikan pengaduan nasabah, maka person in carge dalam pengaduan nasabahtersebut akan mengedukasi nasabah untuk melakukan eskalasi permasalahanpengaduan nasabah tersebut kepada lembaga alternatif penyelesaian sengketa untukdilakukan mediasi permasalahan.

Edukasi atau Pendidikan Konsumen, pada pasal 4 huruf d dan $\mathrm{f}$ UUPK menjelaskan bahwa konsumen memilikihak untuk mendapat informasi yang jelas, benar dan jujur serta mendapat pembinaandan pendidikan konsumen. Pada dasarnya pemberian informasi dan pendidikankonsumen tidak hanya sarana pemenuhan hak konsumen namun juga merupakan sarana menarik nasabah untuk menggunakan produk tersebut. Bank dalammemasarkan produknya juga melakukan edukasi kepada nasabah mengenaiinformasi produk yang ditawarkan.Bank menggunakan 2 metode dalammemberikan edukasi kepada nasabah internet banking yaitu menggunakan mediadan non-media. Pendidikan menggunakan media dilakukan engan cara Bank menyediakan user guide yang terdapat di dalam website Bank. Sedangkanedukasi nasabah internet banking yang dilakukan dengan non-media, edukasi akandiberikan langsung oleh service assistant yang terdapat di dalam masing-masingcabang.

\section{Pengawasan Dunia Perbankan Terhadap Para Nasabah Pengguna Fasilitas Internet Banking}

Kebijakan pengawasan yang dilakukan oleh Bank Indonesia terhadap perbankan bertujuan untuk melindungi kepentingan masyarakat dan serta menjaga kelangsungan usaha bank sebagai kepercayaan dan sebagai lembaga intermediasi, pengawasan tersebut dilaksanakan baik secara langsung ataupun tidak langsung.

Pengawasan tidak langsung adalah pengawasan yang dilakukan dengan meneliti, menganalisis serta mengevaluasi laporan-laporan yang disampaikan oleh suatu bank dengan tujuan untuk mengetahui apakah suatu bank telah melaksanakan ketentuan perbankan sekaligus untuk menilai kinerja perbankan.

Sementara itu, yang dimaksud dengan pengawasan langsung adalah pengawasan dalam bentuk pemeriksaan langsung yang diikuti dengan tindakan-tindakan perbaikan. Sebagaimana diatur dalam undangundang, seluruh bank wajib memberikan kesempatan kepada pemeriksa bank untuk memeriksa buku-buku serta berkas-berkas yang ada pada bank, selain itu bank juga wajib membantu apabila diperlukan dalam rangka memperoleh kebenaran dari segala keterangan, dokumen dan penjelasan yang dilaporkan oleh bank yang bersangkutan (Suseno Piter Abdullah, 2003: 32)

\section{PENUTUP}

\section{Simpulan}

Berdasarkan pemaparan diatas, ada beberapa simpulan yang dirumuskan sebagai berikut:

1. Beberapa bentuk perlindungan hukum nasabah pengguna fasilitas internet banking adalahdengan adanya Peraturan Otoritas Jasa Keuangan No.38/POJK.03/2016 tentang Penerapan Manajemen Risiko dalam Penggunaan Teknologi Informasi oleh Bank Umum (POJK Manajemen Resiko TI). Adanya Pasal 1 angka 12 Undang-Undang No 11 Tahun 2008 tentang Informasi dan Transaksi Elektronik (UU ITE), 
tanda tangan elektronik adalah tanda tangan yang terdiri atas informasi elektronik yang dilekatkan, terasosiasi atau terkait dengan informasi elektronik lainnya yang digunakan sebagai alat verifikasi dan autentikasi. Hal lain yang bisa dilakukan oleh nasabah pengguna fasilitas internet banking adalah Dengan melakukan pengaduan nasabah, Pengaduan nasabah adalah bentuk perwujudan dari perlindungan hak yang dimiliki oleh nasabah yaitu hak untuk di dengar. Hak tersebut diatur di dalam Pasal 4 huruf d Undang-Undang 8 Tahun 1999 tentang Perlindungan Konsumen UU PK). Sedangkan pada sektor jasa keuangan, terdapat Pasal 32 Peraturan Otoritas Jasa Keuangan Nomor 1/POJK.07/2013 tentang Perlindungan Konsumen Sektor Jasa Keuangan (POJK PK) yang mengatur bahwa pelaku usaha sektor jasa keuangan wajib memiliki dan melaksanakan pelayanan dan penyelesaian pengaduan nasabah.

2. Kebijakan pengawasan yang dilakukan oleh Bank Indonesia terhadap perbankan bertujuan untuk melindungi kepentingan masyarakat dan serta menjaga kelangsungan usaha bank sebagai kepercayaan dan sebagai lembaga intermediasi, pengawasan tersebut dilaksanakan baik secara langsung ataupun tidak langsung

\section{Saran-saran}

1. Diharapkan kepada pemerintah untuk selalu melakukan pengawasan terhadap regulasi-regulasi yang ada untuk menjamin keberadaan perlindungan hukum bagi nasabah pengguna fasilitas internet banking.

2. Diharapkan kepada pemerintah, dalam hal ini melalui Bank Indonesia untuk selalu menjaga kepercayaan yang diberikan oleh masyarakat untuk melindungi kepentingan masyarakat dan kelangsungan usaha bank sebagai lembaga intermediasi.

\section{DAFTAR PUSTAKA}

\section{Buku Literatur}

Joan Venzka Tahapary, 2011. Keabsahan Tanda Tangan Elektronik sebagai Alat Bukti yang Sah Ditinjau dalam Hukum Acara Perdata.Tesis Fakultas Hukum, Universitas Indonesia

Peter Marzuki, 2006. Penelitian Hukum, Kencana Prenada Media Group, Jakarta

Satjipto Raharjo.2003. Sisi Lain Dari Hukum Di Indonesia, Kompas, Jakarta

Soerjono Soekamto, Sri Mamudji 2003.Penelitian Hukum Normatif. Rajawali Press, Jakarta

Suseno Piter Abdullah, 2003. Sistem Dan Kebijakan Perbankan Di Indonesia. Pusat Pendidikan dan Studi Kebanksentralan, Jakarta

\section{Peraturan Perundang-Undangan}

Undang-Undang 8 Tahun 1999 tentang Perlindungan Konsumen (UU PK).

Undang-Undang No 11 Tahun 2008 tentang Informasi dan Transaksi Elektronik (UU ITE)

Peraturan Pemerintah Nomor 82 Tahun 2012 tentang Penyelengaraan Sistem dan Transaksi Elektronik (PP PSTE)

Peraturan Otoritas Jasa Keuangan Nomor 1/POJK.07/2013 tentang Perlindungan Konsumen Sektor Jasa Keuangan (POJK PK)

Peraturan Otoritas Jasa Keuangan No. 38/POJK.03/2016 tentang Penerapan Manajemen Risiko dalam Penggunaan Teknologi Informasi oleh Bank Umum (POJK Manajemen Resiko TI)

\section{Jurnal/Website}

Doni Purnama Alamsyah dan Rizki Anugrah.Membangun Kepercayaan Nasabah Pada Internet Banking.EcodemicaVol III No.2 September 2015.

http://www.antaranews.com/berita/588783/ojk-waspadai-dampak-penggunaan-ti-perbankan diakses pada 20 Mei 2019 